British diplomatic service, from which he retired in 1924 in order to take up work in the city of London. In I930-1 he was Manager of the Bank for International Settlements and is now a partner in the firm of Morgan, Grenfell \& Co. For five years (1939-44), with the rank of Major-General, he was in charge of the Civil Administration of Abyssinia, Eritrea and Libya. For some time his headquarters were at Nairobi and he was thus able to make himself well acquainted with conditions in East Africa. The Institute may confidently look to him for wise and expert guidance in the coming years of renewed activity.

\title{
Major Sir Humphrey Leggett, D.S.O.
}

The death of Sir Humphrey was briefly recorded in our last number. If the Institute in its beginnings owed much in several directions to Lord Lugard, Dr. Oldham, and Hanns Vischer, on its business side it owed most to Sir Humphrey, who was appointed a Trustee and Treasurer in 1926. He won distinction in two fields. He started as a soldier with a commission in the Royal Engineers and was awarded the D.S.O. for gallantry in the South African War. During the First World War he was attached to the Belgian War Office and was knighted for his services. Between the wars he was in East Africa on special duty for three years and acted as a non-official member of the Legislative Council of Kenya. He became deeply interested in African commercial enterprise and for twenty-seven consecutive years was chairman of the East African section of the London Chamber of Commerce. To this office, as East Africa and Rhodesia recognizes in its tribute, ' he brought the advantage of an analytical mind, an exceptionally retentive memory, unflagging industry, manifold sources of information, and a wide and influential acquaintanceship '. He exhibited these qualities during his treasurership of the Institute. He was as careful of its finances as if they were his own; he husbanded them assiduously. His exposition of the annual budget was always a pleasure to himself and his hearers. His unfailing tact, his good humour and oldworld courtesy, his readiness to help, his talent of appreciation-all this, with his wisdom, made him an ideal colleague.

\section{The Scarbrough Commission}

The Report of this Commission to which Lord Hailey made reference in his address (see p. 232) has an interest that is not confined to British academic circles and people. It was appointed by Mr. Anthony Eden when he was Secretary for Foreign Affairs to examine the facilities offered by universities and other educational institutions in Great Britain for the study of Oriental, Slavonic, East European, and African languages and culture, to consider what advantage is being taken of these facilities, and to formulate recommendations for their improvement. The members were concerned not only with the teaching of languages but rather the interpretation to the British people of the whole life of the peoples who speak the languages-nearly five-sevenths of the world's population. How do they live, what is their history, as well as how do they speak, are questions which these studies should attempt to answer. In many respects the result of the Commission's inquiries are not flattering to British readers; the "traditional exclusiveness which tends to disregard and even to look down upon culture which has little in common with our own' is the chief reason why these studies have not taken the place they should have taken. 'Interest in other peoples, understanding of their history, their achievements and their characteristics, are a part of the foundation on which lasting international friendships can be built. Unless these studies flourish in this country this interest cannot be satisfied and there can be no such understanding.' With such convictions the Commission put forward many proposals including the provision by Government of 195 post-graduate studentships-of which 50 will be in African studieswith a view to training young scholars who may later fill academic posts. The selected 
students will be required to study for from three to six years, of which not less than a third should be spent in the country or countries to which their studies are related.

Lord Hailey quoted only part of the Commission's favourable references to the Institute. We are particularly pleased by what is said of this Journal. " Africa" is firmly established as a forum for the scientific exposition of questions relating to linguistics, anthropology, sociology, technology, etc. in Africa.'

\section{Planned development in Northern Rhodesia}

During a recent visit to Northern Rhodesia the writer saw some of the amazing changes that have come over the face of the territory since he first crossed the Zambezi forty-five years ago. But until recently there has been no co-ordinated planning, no conscious striving to achieve a balanced and steady progress within a definite policy and towards a definite goal. Now under the impetus given by the Colonial Development and Welfare Fund vast plans have been elaborated which, if carried to success, will affect the life of every inhabitant, African and European. The programme is to be financed partly from the C.D.W. Fund $(£ 2,500,000)$, from existing and future surpluses $(£ 5,500,000)$, and from loans $(£, 000,000)$. In order to guard against a possible fall in revenue, the programme is to be reviewed every three years; and it may be expanded later if revenue increases. Thirteen millions to be spent in ten years may seem a large sum, but it falls short of the requirements. Original estimates here as elsewhere have had to be reduced. The Health Department, for instance, asked for $£ 2,817,900$ in addition to current expenditure and has been allotted $£ 1,598,000$. The curtailment means a service not more than 75 per cent. complete in either geographical extent or technical adequacy. Similarly, the original educational scheme has been drastically reduced by over $£ 900,000$. Provision for linguistic research has (we note with regret) been eliminated.

One feature of the medical programme is the enlargement of the African Medical Training School to accommodate 200 pupils and their wives for the staffing of the new hospitals and dispensaries. There is also to be a school for African sanitary inspectors. The educational programme allows for elementary instruction to be provided for 120,000 children, for 20,700 in higher standards (III-VI), and the training of 2,600 teachers. An important feature is the establishment of a Publications Bureau (at the cost of $£ 5,000$ a year) to encourage reading among Africans by means of libraries, bookstalls, and colporteurs, and to organize the production of books. Twelve trained Africans will be engaged in translation under the supervision of European experts.

The plan for rural development provides for concentrated operations in selected localities and extension work throughout the country. The development centres were described in these Notes when we commented upon Mr. C. F. Clay's tentative proposals (Africa, October 1945). His suggested five Centres have now (in deference to the views of the unofficial members of the Legislative Council) been reduced to one in the first three-year period with provision for a second in the fifth year. The Centres were to be demonstration areas in which accelerated development would be stimulated, and also a means of training the numerous Africans without whose co-operation the plans could not be carried out; it is not clear now how these men and women will receive adequate training. The cost of establishing a Centre is reckoned at $£ 91,000$ for capital expenditure and $£_{34,000}$ per annum recurrent. In addition to, or in the place of, these Centres the plan allows for development areas. In brief, the programme may be outlined as follows. The Territory is to be divided into ten areas corresponding to its natural ecological divisions; and within each area a district will be selected for intensive development and each will be staffed by at least four picked men as Development Officers; these, it is said, must be 'the best we have'. They will have adequate clerical assistance; and they will work under the direction of a provincial 